\title{
Households' Consumption Pattern of Snail (Archachatina species) in Oluyole Local Government Area of Oyo State, Nigeria
}

\section{*OGUNTOYE, TO; FATOKI, OA; ADETOLA, OO; AROWOLO, OV; TOKEDE, AM}

\author{
Forestry Research Institute of Nigeria, P.M.B 5054, Jericho Hills, Ibadan, Nigeria \\ *Corresponding Author Email: gobite2002@yahoo.com; Tel: +2347032255018
}

\begin{abstract}
The present study investigates household consumption pattern of snail meat in Oluyole Local Government Area of Oyo State. A multistage random sampling technique was used to administer the questionnaires to a total of 120 respondents. Data collected were analyzed using both descriptive statistics and inferential statistics. The socioeconomic factors analyzed showed that age group between 31 and $40(45.0 \%)$ consumed snail more while age group between 51 and $60(11.70 \%)$ consumed less snails. The majority of respondents were Married (60.8\%) and possess secondary education (54.2\%). Most of the respondents $(95.8 \%)$ consume snail meat but most of them consume snail meat on a seasonal basis unlike beef and fish. Furthermore, fried form of snail meat is mostly (65\%) preferred when compared to cooked form $(24.2 \%)$. The regression analysis shows that the consumption of snail meat depended on the price, household size, educational level, household income, nutritive value, occupation and its availability. Problems associated with snail meat consumption in the study area include Price, income level, unavailability and cultural belief. Based on the findings, this study recommends that extension workers should engage the public on the need to get involved in the rearing of snails to make it readily available all year round and thus make it more affordable for all sundry.
\end{abstract}

DOI: https://dx.doi.org/10.4314/jasem.v24i7.20

Copyright: Copyright (C) 2020 Oguntoye et al. This is an open access article distributed under the Creative Commons Attribution License (CCL), which permits unrestricted use, distribution, and reproduction in any medium, provided the original work is properly cited.

Dates: Received: 16 May 2020; Revised: 29 June 2020; Accepted: 07 July 2020

Keywords: Snail meat, Consumption, Nutritive Values and Oluyole Local Government Area.

Snails (Archachatina species) are the largest groups of Mollusca, and they belong to the phylum gastropods representing the largest animal groups after arthropods (Yoloye, 2002). Evidence have shown that snail evolved more than 600 million years ago making them one of the earliest known types of animals (Ayodele and Ashimolowo, 1999). Snail meat is rich in minerals such as calcium, phosphorus, potassium, iron and zinc (Babalola and Akinsoyinu, 2009; Engmann et al., 2013), essential amino acids such as Lysine and Arginine can also be found in snail meat (Fagbuaro et al., 2006.). Snails have low cholesterol level which makes them useful in the treatment of arteriosclerosis and other heart related diseases, whooping cough, anemia, ulcer, asthma, age problems, hypertension and rheumatism (Abere and Lameed, 2008). One of the major problems of malnutrition in humans is the low consumption of animal protein (Schönfeldt and Hall, 2012). Report from Food and Agricultural Organization (FAO, 1990) indicated that the average animal protein intake in Nigeria is low. Ayinde and Aromolaran (1998) also reported that Nigeria as a developing country is faced with a worsening situation of inadequate protein consumption which is caused by consumption of mainly starchy foods. As a result of this, under-nutrition and malnutrition affect all age groups and this is widespread in Nigeria today. Nutritionally related diseases are some of the common features of a poorly fed populace such as increasing level of kwashiorkor, delimitating fatigue, other diseases and consequent early death. Unfortunately the popular and regular sources of animal protein in the country like pork meat, beef, goat meat, fish, and poultry products among others are getting out of the reach of common populace due to their high price as a result of the economic downturn (Shaib et al., 1997). Food and Agriculture Organization (FAO) daily recommended per capita animal protein consumption in Nigeria is $9.3 \mathrm{~g} /$ day as against $34 \mathrm{~g} /$ day recommended to be the minimum requirement for the growth and development of the body (Shaib et al., 1997). To make up for this gap, several animal protein sources like snail, cricket, and winged termite are now considered. Snail meat has been reported to be high in protein, low in fat and a source of iron (Ademolu et al., 2004.). Most times snails are gathered from the forests, however, they are also produced through heliculture which is the practice of snail farming. It should be noted that wild snails' population is on the decline due to indiscriminate hunting of snails before they reach 
maturity, bush burning, agro-chemicals, deforestation and change in weather patterns (Efarmspro, 2006).

Religion, age, sex, household size and income are specific factors that determine meat consumption in Nigeria (Okeke, 2015). For instance, pork is unpopular in the Muslim dominated Northern part of the country (Ogunwole and Adedeji, 2014). Several studies have extensively elucidated the consumption pattern of other meat sources in Nigeria but neglecting the Snail meat. Meanwhile, a nutritious food containing quantities of essential amino acids in forms of protein and several health and nutritional benefits which can fill the wide gap and minimize protein malnutrition and by so doing sustain life should be available. As a result of increasing number of protein deficient people in Nigeria, there has been massive campaign to create awareness of the need to improve protein intake. Therefore, affordable sources of protein such as snail have been introduced to households to serve as alternative source to promote protein consumption in the country (Ibirogba, 2019). Hence, this makes the study of the consumption pattern of snail to be worth investigating. The study will specifically describe the socioeconomic characteristics of the respondents, assess their consumption pattern of snail, assess the factors influencing consumption of snail meat and identify the constraints to snail meat consumption in the study area.

\section{MATERIALS AND METHODS}

Study Area: The study was carried out in Oluyole local government area (LGA) of Oyo State. The study area was selected because of the Onigambari forest available in the LGA where households' members can easily get snail for consumption. The LGA is situated in western Nigeria between longitude $03^{\circ} 7 \mathrm{E}$ and $9 \mathrm{E}$ (Larinde and Olasupo, 2011). It was established in 1976 , it has an area of $629 \mathrm{~km}^{2}$ and a population of 202,725 (NPC, 2006). The Local Government is divided into 10 electoral wards namely Ayegun, Idiiroko/Ikereku, Idi-Osan/Egbeda-atuba, Muslim/Ogbere, Odo-ona Elewe, Okanhinde/Latunde, Olomi/Olunde, Olonde/Aba-nla, Onipe, Orisunbare/Ojo-ekun. The study area falls within the humid forest zone of Nigeria and has great potentials for the cultivation of almost all types of forest resources. Maize, Cocoa-yam, plantain and cassava are the major food crops planted in the area. It provides 14 major NTFPs namely Fuel wood, Bush meat, Bitter Kola, Cherry, Sponge, Snails, Walnut, Palm Wine, Broom, Mushroom, Piper, Teak leaves, Irvingia gabonensis (Bush mango or Ogbono) and Rope (Larinde and Olasupo, 2011). Livestock reared in the area are sheep, goats and cattle.
Method of Data Collection and Sampling Techniques: Data for this study was collected with the aid of a structured questionnaire administered to households in Oluyole Local Government Area. Multi-stage sampling technique was employed in selecting households in the study area. The first stage employed random sampling technique in selecting 6 wards (Ayegun, Odo Ona-Elewe, Olomi/olunde, Onipe, Orisunbare and Latunde) out of 10 wards in the study area. The second stage involved systematic sampling selection of 20 households from the selected wards to arrive at a sample size of 120 households.

Analytical Techniques: Data obtained were analyzed using descriptive statistics and multiple regression analysis. The descriptive statistics used include frequency distribution and percentages which was used to describe the socioeconomic characteristics of the respondents, examine consumption pattern of snail meat in the study area and also to identify the constraints to snail meat in the study area. Linear regression was used to analyse the factors influencing consumption of snail meat in the study area. Snail meat consumption model in this study is implicitly stated as:

$$
\mathrm{C}=\mathrm{f}\left(\mathrm{X}_{1}, \mathrm{X}_{2}, \mathrm{X}_{3}, \mathrm{X}_{4}, \mathrm{X}_{5}, \mathrm{X}_{6} \mathrm{X}_{7}, \mathrm{X}_{8}, \mathrm{X}_{9}, \mathrm{U}\right)
$$

Where $\mathrm{C}=$ Quantity of snail meat consumed; $\mathrm{X}_{1}=$ Price of Snail ( $\mathrm{N}) ; \mathrm{X}_{2}=$ Age of respondents (years); $\mathrm{X}_{3}=$ Household size (no of persons); $\mathrm{X}_{4}=$ Level of education (years); $\mathrm{X}_{5}=$ Household income (N); $\mathrm{X}_{6}=$ Marital status (Married $=1$, otherwise $=0$ ); $\mathrm{X}_{7}=$ Taste $(\mathrm{Yes}=1, \mathrm{No}=0) ; \mathrm{X}_{8}=$ Nutritive value $(\mathrm{Yes}=1, \mathrm{No}=0)$; $\mathrm{X}_{9}=$ Snail Availability $(\mathrm{Yes}=1, \mathrm{No}=0) ; \mathrm{U}=$ error term

\section{RESULTS AND DISCUSSION}

Socio-economic Characteristics of Respondents: Table1 shows the socio-economic characteristics of the sampled respondent. The socioeconomic characteristics considered in the study include; age, gender, marital status, educational status, occupation, household size and income. The effect of some of the socioeconomic factors was tested in the regression analysis as they affect the consumption of snail meat. The result shows that $45.8 \%$ of the respondents were males while $54.2 \%$ were females. This implies that females are decision makers in most cases when it comes to household consumption. This result is in line with Adeniyi et al (2013) who reported that 43.7 percent of the respondents were males while $56.3 \%$ were females. The result also indicates that age group between 31 and 40 has the highest representation of $45.0 \%$ of the respondent. This implies that this age group consumes more of snail meat perhaps due to the awareness of its nutritional value. The decline in consumption of snail meat in age group between 51 
and $60(11.7 \%)$ may be attributed to the fact that the decision on what to eat in most households' is no longer in the hands of this age group and also due to lack of awareness on the medicinal value of snail meat in maintaining good health especially in adult. The Majority of the respondents $(60.8 \%)$ were married while $(24.2 \%)$ of the respondents are divorced. This implies that marital status is a deciding factor to snail meat consumption in some households. This result also agrees with Adeniyi et al (2013) who reported that majority of the respondents were married (66.2 percent). Table 1 further reveals that a large percentage of the respondents $(35.0 \%)$ are Artisans followed by those that are civil servants $(23.3 \%)$, Farmers (20.8\%), Traders (17.5\%) and the unemployed respondents $(3.3 \%)$.

Table 1: Distribution of Socio-economic characteristics of

\begin{tabular}{|c|c|c|}
\hline Variables & Frequency & Percentage \\
\hline \multicolumn{3}{|l|}{ Age } \\
\hline $21-30$ & 32 & 26.7 \\
\hline $31-40$ & 54 & 45.0 \\
\hline $41-50$ & 20 & 16.7 \\
\hline $51-60$ & 14 & 11.7 \\
\hline Total & 120 & 100.0 \\
\hline \multicolumn{3}{|l|}{ Gender } \\
\hline Male & 55 & 45.8 \\
\hline Female & 65 & 54.2 \\
\hline Total & 120 & 100.0 \\
\hline \multicolumn{3}{|l|}{ Marital Status } \\
\hline Single & 12 & 10.0 \\
\hline Married & 73 & 60.8 \\
\hline Divorced & 29 & 24.2 \\
\hline Widow & 6 & 5.0 \\
\hline Total & 120 & 100.0 \\
\hline \multicolumn{3}{|l|}{ Occupation } \\
\hline Farming & 25 & 20.8 \\
\hline Artisan & 42 & 35.0 \\
\hline Civil Servant & 28 & 23.3 \\
\hline Unemployed & 4 & 3.3 \\
\hline Trading & 21 & 17.5 \\
\hline Total & 120 & 100.0 \\
\hline \multicolumn{3}{|l|}{ Education } \\
\hline Non- formal education & 8 & 6.7 \\
\hline Primary & 15 & 12.5 \\
\hline Secondary & 65 & 54.2 \\
\hline Tertiary & 32 & 26.7 \\
\hline Total & 120 & 100.0 \\
\hline \multicolumn{3}{|l|}{ Household Size } \\
\hline $0-2$ & 16 & 13.3 \\
\hline $3-5$ & 22 & 18.0 \\
\hline $6-8$ & 78 & 65.0 \\
\hline $9-11$ & 4 & 3.4 \\
\hline Total & 120 & 100.0 \\
\hline \multicolumn{3}{|l|}{ Monthly Income } \\
\hline$<30,000$ & 28 & 23.3 \\
\hline $31,000-60,000$ & 45 & 37.5 \\
\hline $61,000-90,000$ & 21 & 17.5 \\
\hline $91,000-120,000$ & 16 & 13.3 \\
\hline Above 120,000 & 10 & 8.3 \\
\hline Total & 120 & 100.0 \\
\hline
\end{tabular}

The majority of the respondents (54.2\%) had secondary school education followed by those that have tertiary education $(26.7 \%)$. This implies that most of the respondents in the study area are educated, which may have influenced their consumption of snail meat. A good percentage of the respondents $(65.0 \%)$ have household size between 6 and 8 followed by respondents $(18.3 \%)$ that have household size that is less than or equals to 5 , It is possible that respondents with low household size will have the capacity to consume more of snail meat compared to those that have large household size. This agrees with the work of (Ayodele \& Ashimolowo, 1999) that states that household size plays a vital role in snail consumption. About $38 \%$ of the respondents earned income between 31,000 and $60,000,23.3 \%$ earned between 1000 and $30,000,17.5 \%$ earned between 61,000 and 90,000 and only $8.3 \%$ earned between 121,000 and 150,000 . This shows that the respondents are not really having a good monthly income. As income level determines the food consumption pattern of households, this will negatively affect their consumption pattern and they are like to consume less of snail meat if they have to purchase it.

Table 2: Distribution of Respondents Based on consumption pattern and reason for snail meat consumption

\begin{tabular}{|c|c|c|}
\hline Variables & Frequency & Percentage \\
\hline \multicolumn{3}{|l|}{ Snail meat consumption } \\
\hline Yes & 115 & 95.8 \\
\hline No & 5 & 4.2 \\
\hline Total & 120 & 100 \\
\hline \multicolumn{3}{|c|}{ How often do you consume Snail } \\
\hline meats & 0 & 0 \\
\hline Daily & 7 & 5.8 \\
\hline Weekly & 30 & 25 \\
\hline Monthly & 83 & 69.2 \\
\hline Seasonally & 120 & 100 \\
\hline \multicolumn{3}{|c|}{ Total } \\
\hline \multicolumn{3}{|c|}{ Form of snail meat consumed } \\
\hline Roasted & 13 & 10.8 \\
\hline Fried & 78 & 65 \\
\hline Cooked & 29 & 24.2 \\
\hline Total & 120 & 100 \\
\hline \multicolumn{3}{|l|}{ Nutritive value } \\
\hline Yes & 95 & 79.2 \\
\hline No & 25 & 20.8 \\
\hline Total & 120 & 100 \\
\hline \multicolumn{3}{|l|}{ Taste } \\
\hline Yes & 102 & 85 \\
\hline No & 18 & 15 \\
\hline Total & 120 & 100 \\
\hline \multicolumn{3}{|l|}{ Easy to Prepare } \\
\hline Yes & 97 & 80.8 \\
\hline No & 23 & 19.2 \\
\hline Total & 120 & 100 \\
\hline \multicolumn{3}{|l|}{ Source of Snail Meat } \\
\hline Market & 87 & 72.5 \\
\hline Farm & 18 & 15 \\
\hline Buka(food restaurant) & 9 & 7.5 \\
\hline Beer Parlour & 6 & 5 \\
\hline Total & 120 & 100 \\
\hline
\end{tabular}

OGUNTOYE, TO; FATOKI, OA; ADETOLA, OO; AROWOLO, OV; TOKEDE, AM 
Consumption Pattern of Snail Meat in the study Area: Table 2 shows result obtained from respondent on their pattern of snail meat consumption. The majority of respondents $(95.8 \%)$ consume snail meat while 4.2 $\%$ of the respondents do not consume snail meat. Most of the respondents $(69.2 \%)$ consume snail meat seasonally, $25 \%$ consume snail meat monthly and very few of the respondents $(5.8 \%)$ consume snail meat weekly while nobody eats snail meat daily. This implies that most of the respondents probably consume snail meat during the rainy season as it will be more available in large quantities unlike the dry season. Majority of the respondents (65\%) preferred the fried snail meat, $24.2 \%$ prefer the cooked snail meat while $10.8 \%$ prefer the roasted snail meat. A large percentage of the respondents (79.2\%) consume snail meat because of its nutritive value.

This implies that most of the respondents are aware of the nutritional value of snail meat. Furthermore, Table 2 reveals that majority of the respondents $(85 \%)$ consume snail meat because of its taste and $80.8 \%$ claimed to consume snail meat because it is easy to prepare. This is in consonance with the work of Adeniyi et al (2013) who reported that nutritional factor and taste played prominent roles in household consumption pattern but influence as a result of easy to prepare negates the findings of Adeniyi et al (2013). A good percentage of the respondents $(72.5 \%)$ get snail meat from the market followed by $15 \%$ that get snail meat from the farm, $7.5 \%$ from food restaurants while $5 \%$ get their snail meat from the beer parlour. This implies that the respondents getting snail meat from the farm will pay less or no amount to consume while those buying from the markets, food restaurants and beer parlour will have to pay higher amounts to consume snail meat.

Regression Result Showing the Factors Influencing Snail Meat Consumption: Table below 3 shows the regression results of Quantity of snail meat consumed which serve as the dependent variable and explanatory factors such as; price of snail meat, age, household size, educational level, household income, marital status, taste, nutritive value and snail availability as independent variables. The coefficient of Price is negatively significant at 5\% level, showing that if the price increase the amount spent on snail meat will reduce. This is in agreement with Adeniyi et al., (2013) who showed that the coefficient of Price of snail is negatively significant at $5 \%$ level, indicating that an increase in price will lead to decrease in amount spent on snail meat and vice-versa. The coefficient of Household income is positively significant at $1 \%$, indicating that an increase in household income will cause an increase in snail meat consumption. Also the coefficient of educational level is positively significant at 5\%, indicating that the higher the level of education, the more they accept new nutritional knowledge. These results further showed that there is a significant correlation at $1 \%$ between the decision to consume snail meat and the following parameters: Household size, Nutritive value and Snail availability. Table 4 showed that the major problems/constraints associated with snail meat consumption in the study area were Price of snail, followed by financial constraint, unavailability all year round and cultural belief. This corroborates the report of Adeniyi et al., (2013) that scarcity (unavailability all year round), price and cultural belief were major factors hindering the consumption of food products.

Table 3: Regression Results of Respondents Snail meat consumption pattern.

\begin{tabular}{lclc}
\hline Variables & Coefficients & Standard error & T-test. \\
\hline Constant & -0.021 & 0.405 & -0.05 \\
$\mathrm{X}_{1}$ (Price of Snail) & -0.422 & 0.216 & $-1.96^{* *}$ \\
$\mathrm{X}_{2}$ (Age distribution) & 0.041 & 0.036 & 1.16 \\
$\mathrm{X}_{3}$ (Household size) & -0.158 & 0.051 & $-3.09^{* * *}$ \\
$\mathrm{X}_{4}$ (Educational Level) & 0.920 & 0.228 & $4.03^{* *}$ \\
$\mathrm{X}_{5}$ (Household Income) & 0.172 & 0.103 & $1.66^{*}$ \\
$\mathrm{X}_{6}$ (Marital Status) & -0.049 & 0.089 & -0.55 \\
$\mathrm{X}_{7}$ (Taste) & 0.084 & 0.124 & 0.68 \\
$\mathrm{X}_{8}$ (Nutritive value) & 0.253 & 0.077 & $3.29 * * *$ \\
$\mathrm{X}_{9}$ ( Snail availability) & 0.323 & 0.112 & $2.88^{* * *}$ \\
\hline \multicolumn{2}{c}{$* * *$ Significant at 1\%, ** significant at 5\%, * significant at $10 \%$}
\end{tabular}

Table 4: Constraints associated to snail meat consumption in the study area

\begin{tabular}{lcc}
\hline Variable & Frequency & Percentage \\
\hline Snail meat is a taboo in my area (Cultural belief) & 15 & 12.5 \\
Snail meat is irritating & 10 & 8.3 \\
Unavailability all year round & 20 & 16.7 \\
Financial constraint (low income level) & 35 & 29.2 \\
Snail is expensive (Price) & 40 & 33.3 \\
Total & $\mathbf{1 2 0}$ & $\mathbf{1 0 0 . 0}$ \\
\hline
\end{tabular}

Source: Field Survey, 2020 
Conclusion: The majority of the respondents consume snail meat in fried form on a seasonal basis. The respondents that consume snail meat majorly get it from the market, however, most claimed that snail meat is expensive for them to consume. Price, household size, educational level, income, nutritive value and snail availability were the major determinants of snail meat consumption in the study area. Awareness creation on the nutritional benefits of snail meat should be strengthened and extension agents should engage more people in snail rearing to make it more affordable, generate more income and available all year round.

\section{REFERENCES}

Ademolu, K. O; Idowu, A. B; Mafiana, C. F; Osinowo, O. A (2004). Performance, proximate and mineral analyses of African giant land snail (Archachatinamarginata) fed different nitrogen sources. African Journal of Biotechnology. 3(8): 412-417

Abere, S.A; Lameed, G.A (2008). The Medicinal Utilization of Snails in Some Selected States in Nigeria. In: J.C Onyekwelu, V.A.J Adekunle, D.O Oke (Eds.): Proceeding of the First National Conference of the Forest and Forest Products Society (FFPs) held in Akure, Ondo State between 11th and18th of April, 2008; 233-237.

Adeniyi, B; Shobanke I; Omotoso A (2013). Economic Analysis of Snail Meat Consumption in Ibarapa

Central Local Government Area of Oyo State. Journal of Marketing and Consumer Research. 2: 16-21

Ayodele, I. A; Asimalowo, A. A (1999). Essential of snail Farming. A technical guide to snail Farming in the tropic publication, Ibadan; 5-43.

Babalola, O.O; Akinsoyinu, A.O (2009). Proximate Composition and Mineral Profile of Snail Meat from Different Breeds of Land Snail in Nigeria. Pakistan Journal of Nutrition. 8(12): 1842-44.
Engmann, F.N; Afoakwah, N.A; Darko, P.O; Sefah, W (2013). Proximate and Mineral Composition of Snail (Achatina Achatina) Meat; Any Nutritional Justification for Acclaimed Health Benefits? Journal of Basic and Applied Science Research. 3(4): 8 - 15 .

Efarmspro, (2006). Snail Farming and Management. From $<$ URL www.efarmspro.com $>$ (Retrieved on 29th of February, 2020).

Fagbuaro, O; Oso, J.A; Edward, J.B; Ogunleye, R.F (2006). Nutritional Status of Four Species of Giant Land Snails in Nigeria. J. Zhejiang Univ. Sci. 7(9): 686 - 689.

Ibirogba F. (2019). Why Protein Deficiency is a National Emergency. The Guardian Newspaper, $8^{\text {th }}$ Novenmber, 2019. PP 26

Ogunwole, O. A; Adedeji, B.S. (2014). Consumers' Preference and Perception of the different Types of Meat among Staff and Students of the University of Ibadan, Nigeria. J. Agric. Environ. Sci.. 3(2): 77 - 95.

Okeke, U (2015). Economic of Snail Rearing in Ndukwa West Local Government Area of Delta State, Nigeria. J. Sci. Multidis. Res. 7(1). 57-67

Schönfeldt, H.C; Hall, N.G (2012). Dietary Protein Quality and Malnutrition in Africa. British Journal of Nutrition. 108(2): 69 - 76.

Shaib, B; Aliyu, A; Bakshi, J.S (1997). Nigeria National Agricultural Research Strategic Plan, 1996 - 2010. Federal Ministry of Agriculture and Natural Resources, Abuja.

Yoloye, V. L (2002): Basic invertebrate zoology. Ilorin. University Press. Pages $134-144$. 